\title{
UPGRADING THE NETWORK OF HIGH MOUNTAIN SHELTER AS A METHOD OF RESTORING OF DEMOGRAPHICALLY ENDANGERED SETTLEMENTS IN THE SLOVENIAN ALPS
}

\author{
Ilka Čerpes ${ }^{1}$, Nina Pandol ${ }^{2}$, Alenka Fikfak ${ }^{3}$
}

Received 31 October 2012; Accepted 9 July 2014

\begin{abstract}
The paper focuses on the interdependence between the development of demographically endangered settlements and the frequency of mountain accidents in the Triglav National Park in the Slovenian Alps. Using statistical data analyses of the Mountain Rescue Association of Slovenia, field surveys and spatial information of the Surveying and Mapping Authority of the Republic of Slovenia, conclusions were reached, which redefined the existing settlement pattern of alpine shelters and mountain pastures, to encourage safe mountaineering and the development of tourism. The upgraded network of Alpine posts is designed as an upgrade of the existing system of providing safety for the visitors to the high mountain regions of the Triglav National Park. At the same time, it offers a new format of tourist services as an opportunity to develop local economies in demographically endangered environments. The dual function (rescue services and tourism) reduces investment and maintenance costs and increases the efficiency in the exploitation of the network of paths and Alpine posts, hence it is feasible also in demographically endangered areas. It is one of the operational tools for stopping further decline in population.
\end{abstract}

Key words: demographically endangered settlements, mountain accidents, Triglav National Park, hiking, tourist development, Alpine settlement, Alpine huts and shelters

Povzetek: $V$ prispevku je predstavljena soodvisnost med razvojem demografsko ogroženih naselij in pogostnostjo nesreč $v$ gorah $v$ Triglavskem narodnem parku v slovenskih Alpah. S pomočjo analiz statističnih podatkov Gorske reševalne zveze Slovenije, ogledov terena in prostorskih podatkov Geodetske uprave Republike Slovenije so bile izpeljane sintezne ugotovitve, ki ponovno definirajo obstoječi poselitveni vzorec gorskih zavetišč in pastirskih planin $\mathrm{z}$ namenom spodbujanja razvoja varnega visokogorskega pohodništva in tudi turizma. Dopolnjena mreža planinskih postojank je zasnovana kot nadgradnja obstoječega sistema zagotavljanja varnosti obiskovalcem visokogorja $v$ TNP. Je hkrati nova oblika turističnih storitev kot priložnost za razvoj lokalnih ekonomij v demografsko ogroženih okoljih. Dvojnost

\footnotetext{
${ }^{1}$ Doc. Dr. Ilka Čerpes, PhD., Faculty of architecture, University of Ljubljana, Zoisova cesta 12, Ljubljana; e-mail: ilka.cerpes@fa.uni-lj.si

2 Nina Pandol, Faculty of architecture, University of Ljubljana, Zoisova cesta 12, Ljubljana; e-mai: nina.pandol@mail.co

${ }^{3}$ Doc. Dr. Alenka Fikfak, PhD., Faculty of architecture, University of Ljubljana, Zoisova cesta 12, Ljubljana; e-mail: alenka.fikfak@fa.uni-lj.si
} 
funkcije (reševalna služba in turistična ponudba) znižuje investicijske in vzdrževalne stroške ter povečuje učinkovitost izrabe omrežja poti in postojank, zato je izvedljiva tudi v demografsko ogroženih območjih. Je eno izmed operativnih orodij za ustavitev nadaljnjega upadanja prebivalstva.

Ključne besede: demografsko ogrožena naselja, nesreče $v$ gorah, Triglavski narodni park, pohodništvo, turistični razvoj, alpsko naselje, nove oblike gorskih poselitvenih vzorcev, gorske koče in zavetišča

\section{Introduction}

In our modern time of global industrial and information society, the novelty in the attitude towards sustainable development is above all in the changed manner of thinking. We need to think about its impacts and consequences, change it if necessary in order to preserve to the highest degree possible not only local but world resources as well (Lemon et al., 2004). Tourism and recreation have also negative impacts on the space and environment: they are mostly demonstrated through the mass nature and large scale tourist capacities. Owing to high tourist consumption, they do tend to have favourite economic effects but at the same time they are the reason for the degradation of the space, the degradation being the most pronounced when saturation arises and its bearing capacity is exceeded.

Bearing capacity means "the degree of development which is still allowed without detrimental consequences for the resources, to wit, environment« (Hudman and Hawkins, 1989: 238-239). The issue of the bearing capacity in protected areas has been addressed by several other authors (e.g. Garrigós Simón et al., 2004; Lawson et al. 2003; Prato, 2001; Jurinčič, 2004). The motivation of visitors of protected areas has also received much attention (Holden and Sparrowhawk, 2002; Ballantyne et al., 2008; Van der Merwe and Saayman, 2008; Lovén, 2000). As some studies suggest (e.g. Reinius and Fredman, 2007), among protected areas, national parks have been found to be of most significance in terms of tourism and tourist attractiveness. According to the International Union for Conservation of Nature (IUCN), tourism and recreational use in national parks are acceptable if they neither interfere with the aim of natural conservation in the area nor cause degradation to the natural resources (Dudley, 2008).

However, far less studies have examined the problem of mountain accidents, other problems in the mountain, mountaineering and mountain rescue missions (Kirkman, 1966; Shimanski 2008; Heggie and Amundson, 2009). Notably, as early as in 1966, Kirkman wrote about the following issues that remain relevant today: "In these days of increasing leisure many more people than formerly are going to the hills for recreation and exercise ... In addition, the number of walking, rambling, and mountaineering clubs continues to grow ... This increase in numbers has brought an increase in the number of accidents and acute illness taking place in the hills."

From the point of view of the development of contemporary forms of tourism we are mainly interested in the not easily accessible mountain rural areas where dispersed settlement prevails. The latter is defined in the Strategy of Spatial Development of Slovenia (2004) as a spatial form, to wit, a concept which defines a large number of small settlements dispersed in the space which are classified as to their type into fragmented, dispersed and scattered settlements as part of the autochthonous settlement. However, in the study, demographically endangered areas and settlements are addressed in more detail from the viewpoint of spatial development. In Slovenia, demographically endangered areas as a phenomenon have been recognised since 1990, with the passing of the Act on Development Promotion in Demographically Endangered Areas (1990), which was replaced with the Act for Promotion of Balanced Regional Development Act (1999). Similar definitions of demographically endangered areas in Slovenia were proposed by Klemenčič (1974), Kladnik and Ravbar (2003), Nared (2004) and others. In Articles 1 - 3 of the Decree on Regions Deemed as Demographically Threatened Regions in the Republic of Slovenia (1999) the demographically endangered settlements of Slovenia are defined. 


\section{Alpine space and landscape}

On the European scale, the Alps represent an interesting space for examining demographic, social, cultural and economic changes. Owing to their distinctive geographic features, difficult accessibility and permeability in both directions, i.e. North-South and East-West, they have for centuries and millenniums represented a special region within the European space. Recently, The European Commission and other international organizations such as for instance CIPRA (French abbreviation for Commission International pour la Protection des Alps) have concerned themselves with the quality of life in the Alps, promoting equal employment opportunities, resilience of towns, with demographic changes and topical problems in the Alps; together these organisations have found that the Alps are our common living space, a place of leisure activities, that it is in the Alps where our future lies and it is there that we must cooperate. The main initiator of the way of thinking and operating is the Alpine Convention ${ }^{4}$ that has its origin in an initiative by CIPRA.

Under the Alpine Convention, on the basis of cadastral communities, the surface of the Slovenian Alps comprises $7,336 \mathrm{~km}^{2}$, which represents just over one third $(36.2 \%)$ of the territory of Slovenia (Plut, 1999). In the Slovenian Alps, $1,186 \mathrm{~km}^{2}$ of the territory, $14.3 \%$ of surfaces (Ibid.) are under protection. The protected areas of the Slovenian Alps represent as much as $89 \%$ of all protected surfaces of the state, which on the one hand underlines the extraordinary significance of natural protection of the Slovenian Alps while, at the same time, in view of the landscape variation of Slovenia, it represents a major non-equilibrium (Ibid.). For mountain areas, i.e. the entire Slovenian Alpine Space, the Strategy of Spatial Development of Slovenia (2004) envisaged that ecologically-oriented tourism, ecological farming and the use of renewable energy resources are encouraged; for this, there are many opportunities in these areas, and support is ensured to mountain and hill communities (Ogrin et al., 2011).

Structural changes have caused the Alps to be losing their traditional rural peasant image and lead to an ever growing urbanisation (Bairoch, Batou, Chèvre, 1988; Mathieu, 1998; in: Batzing et al., 1996: 336). Certain areas have given in to the impact of tourism and have been restructured into tourist regions. However, on the other hand the process of "tourist urbanisation" has had an impact also on vacating and closing down of less attractive, more poorly geared and less accessible areas of the Alps. Even to this day it has been repeated over and over again that "the parallel product of the Alpine agriculture is an untouched and consequently aesthetically attractive landscape" (Jeršič, 1999). It is the agricultural use that has substantially contributed to a finely broken down, diversified and ecologically variegated Alpine landscape which - from the point of view of human settlement - has nevertheless remained within the limits of a rational soil use.

The contrasts between the development- and protection-related interests are best expressed in the area of valuable natural and cultural features and in certain most frequently visited areas of the Alpine space. Broggi (1998: 120, in: Plut, 1999) has established that the Alpine landscape is threatened by a major change as soon as within the time limits of one or two generations. He has raised several basic questions (Ibid.):

1. The question concerning the future of the Alps: will the Alpine Space be vacated in the future and become an area of wilderness;

2. The question concerning the preservation and survival of Alpine agriculture, in particular on larger surfaces, and

3. The question concerning the costs of landscape care (will higher costs be borne by everyone or by tourism only?).

Beside the general aging trend of the Europeans there exist additional Alpine-specific factors of regionally different influences: migration (in-out), commuting (rural to urban areas) settlement and housing (costs-quality), change of regional demand for public services (e.g. transport,

\footnotetext{
${ }^{4}$ http://www.alpconv.org/pages/default.aspx
} 
healthcare, education) or the change of consumer behaviour in key economies (e.g. nutrition, tourism $)^{5}$.

\section{The Triglav National Park (TNP)}

The Triglav National Park (hereinafter: TNP) (Figure 1) is an exceptional natural and cultural heritage site of the Slovenians, and one of the oldest national parks in Europe. TNP is the common value of the Julian Alps tourist region. Noteworthy, it is the only national park in Slovenia. It was named after Triglav, the highest mountain in the heart of the park, and, incidentally, the highest Slovenian mountain. In the area of the Triglav Lakes, the national park was conceptualized as early as in 1906, while in 1981 it was established in the form that is has today. It covers almost the entire Julian Alps area in the Slovenian territory. It extends on an area of 880 square kilometres, i.e. four percent of the territory of Slovenia ${ }^{6}$. In the park, Triglav $(2864 \mathrm{~m})$ is at the highest elevation point, while the lowest elevation of the park is in the Tolmin Gorges. Inside the Triglav National Park, the territory covers a unique natural and cultural heritage of Slovenia.

The Triglav National Park Act lays down the protection regime of the area, which is performed in two stages. In its central part, the priority is nature protection, while the area is also intended for study, education and visiting. In its peripheral (buffer) area, occupied and managed by inhabitants, more stress is on cultural landscape protection and the encouragement of sustainable management and locally characteristic activities. Besides the Triglav National Park Act, this unique Alpine area is protected by the Constitution of the Republic of Slovenia (Articles 71, 72 and 73), Environment Protection Act, Nature Conservation Act, Water Act, relevant agriculture and forestry acts, and other relevant acts, and the protocols of the Alpine Convention. The most recent guideline originates from the Seville Strategy for Biosphere Reserves, since the Julian Alps were declared a biosphere reserve by UNESCO in July 2003 (ibid.).

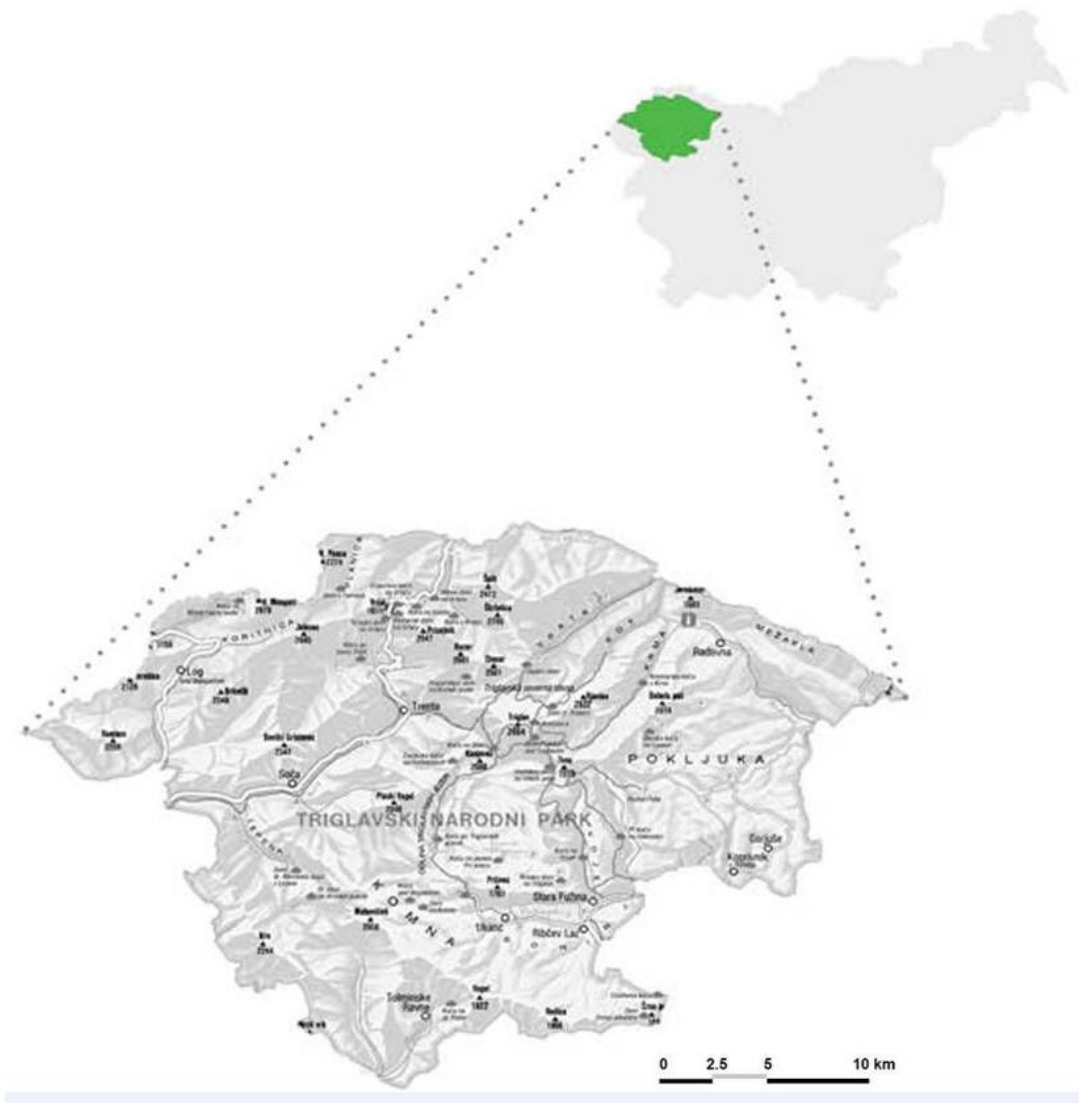

Fig 1. Triglav National Park (TNP) area (http://www.tnp.si/).

\footnotetext{
${ }^{5}$ http://www.demochange.org/

${ }^{6}$ http://www.tnp.si/
} 
The relief is one of the main factors which have had an impact on the emergence of settlements in the area of the Slovenian Alps. The majority of rural settlements in this area is characterised by their being situated at the edges of valleys, sunny slopes and slightly sloped river terraces at foothills and main roadways. Over time, the consequences of natural disasters (earthquakes, natural hazards) and social impacts (wars, industrialisation processes, changes in agricultural management) contributed to the image of the cultural landscape which, owing to mass discontinuation of farming and emigration of young population, became more and more vacated. Consequently, the number of abandoned villages grew, and life on isolated farms stopped. Discontinued, overgrown and unutilised agriculture areas sometimes obtained with difficulties kept slowly but persistently changing the image of the landscape.

\section{Research questions}

The study sought to find the connectivity between the process of depopulation in the demographically endangered settlements and frequency of mountain accidents in the TNP, which is, indeed, connected to the development of the entire Slovenian Alpine space, through the incorporation of modern, and preservation of traditional, tourist activities. The Triglav National Park (TNP) area is considered as an area of dwindling population, while several settlements are considered either as demographically endangered areas or demographically endangered border areas (Decree on Regions Deemed as Demographically Threatened Regions in the Republic of Slovenia, 1999). The following issues were addressed:

- In what areas are the demographically endangered settlements identified;

- Is the decline in population spatially connected to the areas of mountain accidents;

The aforementioned ideas will be discussed with regard to

- nature of the spatial shift into modern concepts of sustainable spatial development that are supposed to prevent further population decline and could be a part of the rescue service network;

- design elements/factors offered by the existing settlement as an established quality;

- quality elements in the design of new settlement patterns that would boost tourism;

- modern ways of the culture of living and leisure activities, along with changes in the way of life, reflected in the design of new spatial activities, such as, for example, the reinforcement of huts and bivouacs network by reusing existing abandoned built structures.

Based on the aforementioned issues and baselines, the following research goals were defined, based on a three-part division: Outline of characteristics of the TNP study area, with an emphasis on the location of demographically endangered settlements; evaluation of the conditions of the built environment, valuation and spatial analysis of mountain accidents; development of modern settlement patterns from the point of view of promoting the development of sustainable tourism in the wider area of TNP. The key research topic is the following: Can the establishment of a system connecting the existing and new programmes on the one hand and the elements of modern and traditional Alpine architecture in less accessible regions also on the other hand provide an opportunity for sustainable spatial development and, as a result, prevent further population decline and diminish mountain accidents?

In studying the relationships of countryside-demography-accidents-tourism-sustainability, we focused on the following: How to prevent the continuation of the negative spatial aspects (i.e. depopulation, mountain accidents) and at the same time ensure the co-existence of traditional rural architecture and modern architecture, which should influence the stability in sustainable forms of living and connections with tourist activities? In this sense, the system is supplemented by the different forms of ecotourism, which means journeys to natural areas but with a responsible attitude towards nature which at the same time stimulates well-being of local population « (TIES, 1990). Ecotourism is a concept of sustainable, more ethical and responsible tourism which does not include only the issues of preserving the environment but cultural, economic and political ones as well (Holden, 2006). How should be all these elements 
connected into a "story of attractiveness", which will serve as a basis for balanced spatial development, while ensuring stability in population structure?

\subsection{Methods and data sources}

The study of the connectivity between the problem of depopulation in demographically endangered settlements and mountain accidents in TNP was broken down into several stages: the processing of statistical data on demographic changes, review and interpretation of spatial data, analysis of statistical data related to mountain accidents, application of statistical data to space, application of the spatial concept of a new connectivity system of mountain path, and the formation of a model for development of modern settlement patterns of alpine architecture to encourage safer sustainable leisure activities and well-being of local population.

Based on the results of the survey conducted among 912 random mountaineers in Slovenia (Cigale, Lampič, Mrak, 2010), the majority of tourists visits TNP during all seasons (42.2\%), while $29.0 \%$ visit TNP in summer only. Mostly, the tourists bring along a family $(35.2 \%)$ or a partner (29.8\%) (ibid.). Daily visitors prevail (55.4\%), while only $3.5 \%$ tourists were accommodated elsewhere, i.e. outside the Upper Sava River valley (ibid.). According to the socio-economic analyses of TNP (Marolt, Smukavec, Zupan, Mlekuž, 2012), the respondents feel that the largest development possibilities, in terms of new vacancies and improved quality of life, are in tourism, agriculture and ancillary services on farms.

According to the Mountain Rescue Association of Slovenia (MRAS, 2011) in the year 2010 alone, 364 rescue missions were performed involving 386 people, of which 156 were injured and 45 dead.

Nowadays, Alpine architecture represents a precious and invaluable case of settlement culture not only of the Slovenians, but of all Alpine nations that have developed a growing appreciation of the Alpine space through their ecologically minded social awareness. Alpine architecture represents an important category of modern Alpine tourism boasting a clearly defined evaluation of its goals. Alpine culture and architecture become important precisely because of their emergence under extreme conditions at the edge of civilization and isolated from the outside world. It is not only the intensity of the experience of the nature and environment that counts: the new form of leisure time activities should involve educational elements, research and presentations/explanations as well (Fikfak, Rozman, 2009).

\subsection{Population change statistics}

First, the first step in the study on prevention of further demographic decline in the TNP area is discussed. The TNP area is sparsely and unevenly populated. Most of the major settlements developed at the contact points of valleys and below mountain passes (Bovec, Bled, Kranjska Gora, Tolmin, Kobarid and Jesenice). The less favourable positions on prominent terrain and higher terraces were occupied by hamlets and, particularly, solitary farmsteads. During the agrarian period, high mountain areas were included in agricultural management, reaching to the highest pastures where livestock, along with some population, was brought during summer. In smaller, more remote settlements, the population is in decline.

Based on the socio-economic study of TNP (Marolt, Smukavec, Zupan, Mlekuž, 2012), the indicators about population, land use and accessibility of the settlements were additionally checked and the data were updated as it is shown on Figure 2. The study covers 34 settlements belonging to 5 municipalities: Bohinj, Bovec, Gorje, Krajnska Gora and Tolmin. Mostly peripheral parts of the mentioned municipalities are situated in the area under study except of Kranjska Gora where also the centre of the municipality can be found there. Only two settlements (Kranjska Gora and Mojstrana) have more than 1,000 inhabitants ${ }^{7}$. There are 4 villages with $500-1,000$ people, 5 villages with 200 - 500 people and remaining 23 settlements less than 200 inhabitants (10 of them having less than 50 inhabitants).

\footnotetext{
${ }^{7}$ Population numbers in this section of the paper are based on the data of the Statistical Office of the Republic of Slovenia, Ljubljana.
} 
Between January 2008 and July 2013 the population number of the area decreased from 9,345 to 9,204 which represents not very alarming $14 \%$. Of it, 14 settlements registered population increase, 18 population decrease and remaining two kept the same population number. It seems that the area is not demographically endangered in general. But the situation of individual settlements can be different.

Some of the settlements could be endangered by simple low population number - sensitive to every fluctuation. Seven settlements have less than 20 inhabitants: Bavšica, Stmec na Predelu, Tolminske Ravne, Goreljek, Žlan, Perniki and Radovna. Surprisingly, three of the mentioned settlements registered population increase and additional two have a stable population.

The age structure is the second stressing factor. In July 2013, there lived 1,209 children under 15 years in the area whereas the number of seniors (over 65) was 2,071, which represents $22.5 \%$ inhabitants. Four settlements have no children at all. In 14 cases the number of seniors exceeds the number of children twice and more. The region is distinctly impacted by aging. From it follows that the population basis is poor or faces the squeeze. The total fertility rate (i.e. average number of children per woman) for Upper Carniola statistical region which covers the area under study was 1.55 in 2011 which is deep under reproduction level. To conclude, it is not possible to expect that the territory of TNP could ensure the positive population development from its own sources.

The migration remains. Unfortunately all five municipalities lost inhabitants by migration in the period 2008 - 2013; although the loss is not so extreme: 605 in total, of it 327 was lost in the municipality Tolmin. The question sounds not only whether the area of TNP is able to keep its population but how to attract new settlers to substitute the losses. The naturbanization process (Pallarés-Blanch et al., 2014) could be one of the theoretical conceptions.

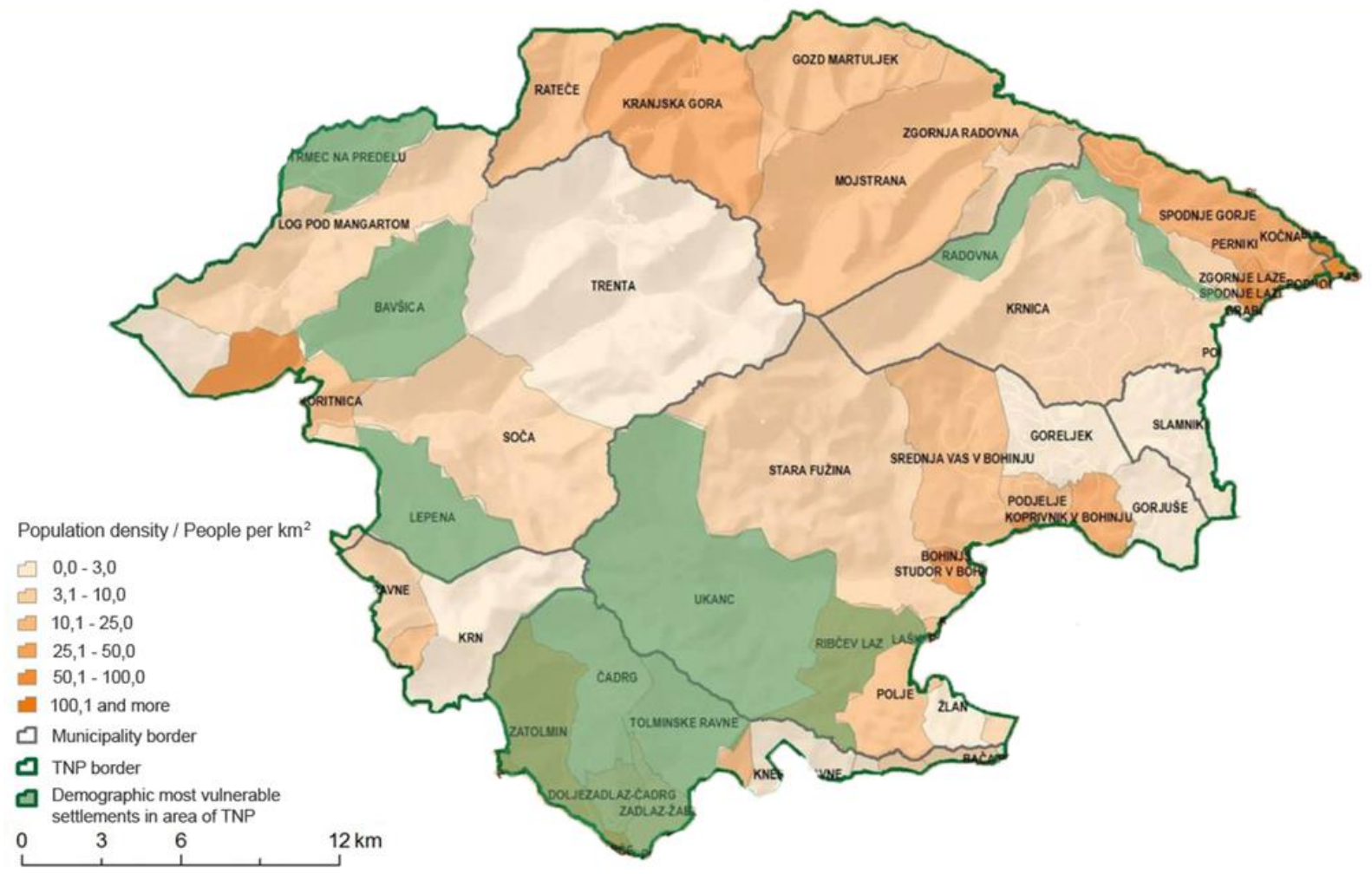

Fig 2. Population density and demographically most endangered areas in TNP. Source: SI-STAT, 2011, and Marolt, Smukavec, Zupan, Mlekuž, 2012.

\subsection{Spatial data}

The second step in studying the TNP area was carried out in parallel to the study of demographically endangered settlements (i.e. the first step of the study), and included the review of spatial data (source: Slovenian Environmental Agency, 2009) showing the conditions and/or impacts on spatial features: map of protection stages; geological map; 
average snow cover in the period of 1971 - 2001; landslides; average duration of solar radiation - summer 1971 - 2001; average annual air temperatures in the period 1971 - 2000; average annual wind speed $10 \mathrm{~m}$ above the ground 1994 - 2001 (Figure 3).
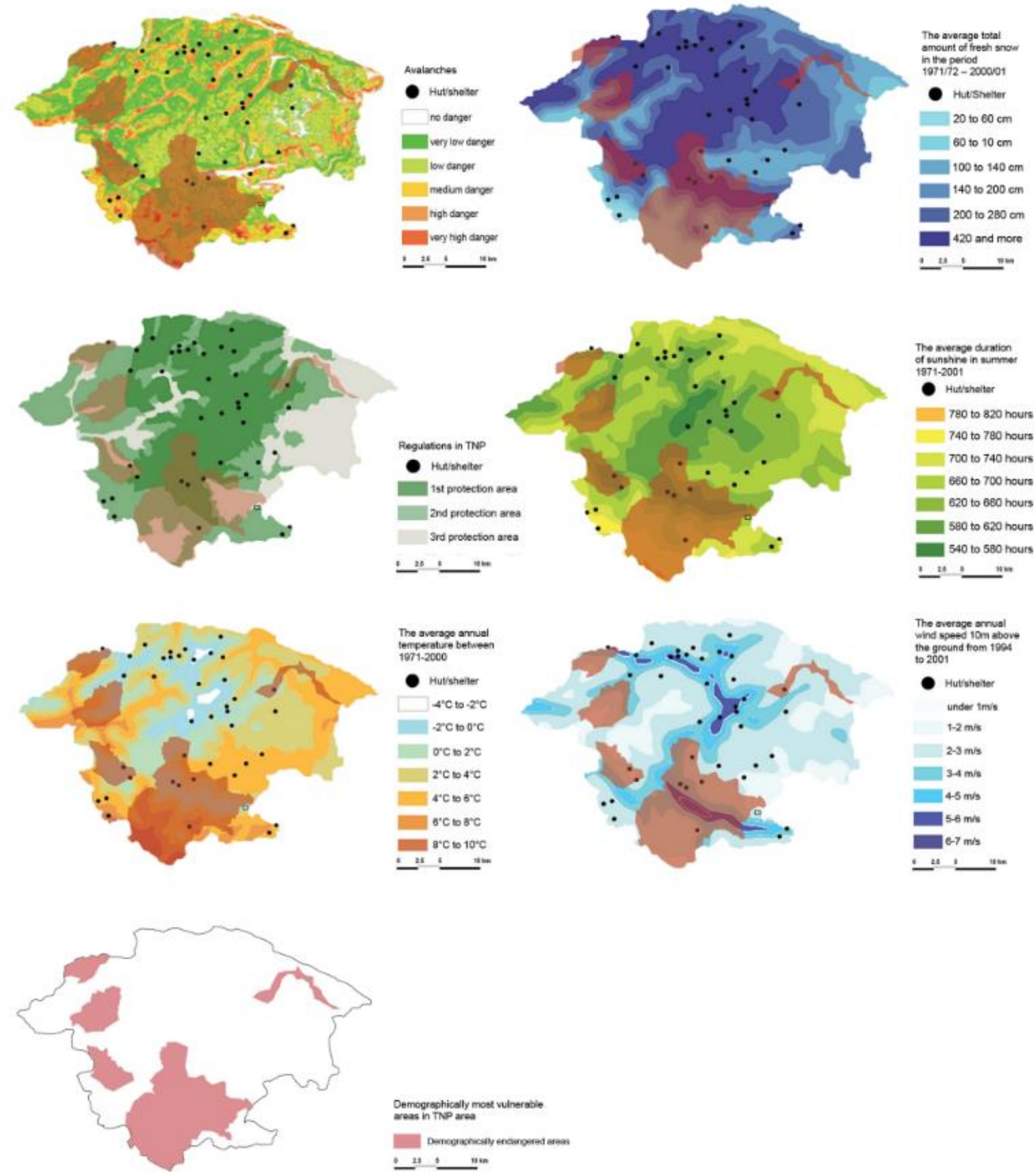

Fig 3. Overview of spatial data in the TNP area. Source: Agencija RS za okolje (2009).

The general conclusions of the data analysis are the following:

- The areas of demographically endangered settlements are in the first and second levels of the TNP protection regime. Only the area of Ukanc is in the third-level protection regime, while in all other settlements the areas of the third-level protection regime are underrepresented.

- The average total snow cover is the highest in the areas of Ukanc, Ribčev Laz and Lepena.

- Landslide risk is the highest in the south of TNP, in the periphery of settlements Ukanc, Ribčev Laz, Čadrag and Tolminske Ravne. 
- The average solar radiation duration is the lowest in Ukanc, Ribčev Laz, Lepena.

- Average air temperatures are the highest in the areas of settlements Čadrag, Tolminske Ravne, Zatolmin, Zadlaz-Čadrag and Zadlaz-Žabče.

- The average wind speed is the highest at the edges of settlements Ukanc, Ribčev Laz, Čadrag and Tolminske Ravne.

\subsection{Method for identification of Alpine settlement patterns}

The mapping was done in the field. In the spatial inventory, we focused on the presence of particular settlement patterns based on the division: isolated (individual) farmstead, isolated building, hamlet and town or city. In this way, different settlement patterns and cases of Alpine architecture in TNP were mapped. In the society, a general belief is that Alpine architecture and settlement culture should be preserved, conserved and protected against the damaging anthropogenic impacts, i.e. uncontrolled economic, energy supply and tourist activities. A conscious change in the use of abandoned dwellings and cheese dairies into tourist accommodation buildings, apartments, managed and unmanaged shelters provides a way to preserve these buildings, while mountaineers and ski mountaineers are supplied with shelter and access to the mountains (Kajzelj 2011, 8).

At this stage, the morphological characteristics of the settlement patterns were not the subject of the investigation. The study was oriented into the possible presence of a particular settlement pattern. The different settlement patterns were entered into a topographic map in the scale of $1: 5,000$. Field work was accompanied with interviews with the local inhabitants; we wanted to explore the different interactions and recognize the possibilities for improvement of living conditions, by introducing new activities that would enable the development of sustainable tourism and reduce mountain accidents. We were especially interested in the criteria that were being considered by individuals when starting a new business (e.g. rural tourism), establishing new mountain huts, production, door-to-door food sales and similar. In interpretation of the results we became aware that the relationship between the people and the location, i.e. the activity, is an important part of preservation and establishment of new patterns, while continuing with the dispersed landscape pattern, with the intention of indirect protection of man in his leisure time activities (mountaineering etc.).

The new organization of connections and interventions (model application) and an inventory of the existing bivouacs is achieved through visual assessment and information provided by the relevant users.

\subsection{Mountain accidents}

Mountain accidents date back to the times when man began to venture into mountain regions. Mountain rescue has been organized for about a century and mountaineering as a leisure pursuit has become popular among all social strata. The popularity of mountaineering is clearly illustrated by the fact that as much as $60-65 \%$ of all leisure-time-related accidents occur during mountaineering, that is, during trips to the mountains (Prebilič, Svete, 2006). According to the Mountain Rescue Association of Slovenia (MRAS, 2011), the Slovenian mountains receive approx. 2.5 million visitors each year and, in 2010 alone, 364 rescue missions were performed involving 386 people (Figure 4; data by MRAS, 2011), of these 156 were injured and 45 dead. The rescuers performed 13,221 rescue hours (ibid.). The number of accidents not related to mountain activities has grown.

The third step in the study was the statistical analysis of mountain accidents. This part of the research was performed in the first stage and was related to the area covered by all mountain rescue groups in Slovenia; hence it was not limited exclusively to TNP. The analysis was performed based on the data provided in the analysis of accidents and rescue work (GRZS, 2011). The data reveal some characteristics that could be related to social and political changes. These are the following (after Prebilič, Svete, 2006):

- Way of life leading to poor physical condition of individuals and lack of free time: As a result, people try to make use of each free moment and visit the mountains when they have time, 
and not when they are physically ready or when the season and weather conditions are right. The result of this is many MRAS rescue missions, which are now typically underway in medium mountain regions and hills in the vicinity of major towns and cities. Such interventions are also health related, since the overexertion will lead to cardiac arrest, muscle strains, severe sprains and dislocations, and fractures.

- Mountain rescuers have become indispensable in the rescue missions outside the Slovenian mountains, i.e. in rescuing from high buildings and during other types of accidents. The main reason for their inclusion in such rescue missions lies in the high level of expertise, reliability and quick reaction time, along with suitable technology and gear.

- Extreme, or adrenaline, sports pose particular challenges to the rescuers. In such accidents, additional qualifications and proper gear are necessary. There is a growing number of rescue missions in deep holes, of parachutists from precipitous slopes and similar.

- Visits to the mountains and hills by foreigners. The number of foreign mountaineers in Slovenia is growing, which is the result of integration in the Euro-Atlantic community, and of the geographic position of Slovenia. Many visitors come from traditionally non-alpine countries or countries where mountaineering is less developed than in Slovenia. These visitors often underestimate the mountains; they are typically ill-equipped and physically illprepared. Unfortunately, their alpine culture is often low and the rescue missions are made even more difficult (they neglect to communicate their destination in the mountain huts, overconsumption of alcohol, etc.).

Using statistical analyses (data by MRAS, 2011), the following syntheses were derived, which were important for the analysis and establishment of sustainable eco-tourism and settlements with sustainable population development:

- Most frequently, the accidents occur in the Julian Alps area, which coincides with the study area of TNP.

- The study area includes the region of high mountains between $1601-2000 \mathrm{~m}$ a. s. I. within the Julian Alps.

- An upgrade of the existing situation (shelters, huts) is important, as well as the establishment of connectivity, by locating a central zone, which would enable unity and connectedness.

- The most common cause of accidents is slip or fall, which suggests that in the future the rescue shelters should be located along the more demanding mountain paths.

- The types of rescue missions provide information about the equipment of the individual bivouacs and their design.

- The rescue bivouacs are to operate primarily during summer. During the rest of the year, a form of emergency (on-call) services is formed.

- The target groups are mountaineers and people who undertake air sports.

- In parallel to this, we made an inventory of the existing bivouacs and checked their distance from the settlements with permanent residents. To this end, field work was necessary, since statistical data did not provide enough information. However, the situation in the field changes constantly, which is related to the change in demographics (aging of population). Today in the Julian Alps there are 58 mountain huts and shelters, of which 35 huts and 5 bivouacs are located inside the TNP. The mountain huts as the basis of mass mountaineering have a social significance. They offer shelter, accommodation, food and drink, and serve as MRAS information points. With rescue bivouacs, we can reduce the number of death casualties in the mountains, and ensure more efficient rescue missions. Importantly, these points should be connected with the local population who protect and maintain the cultural landscape. 

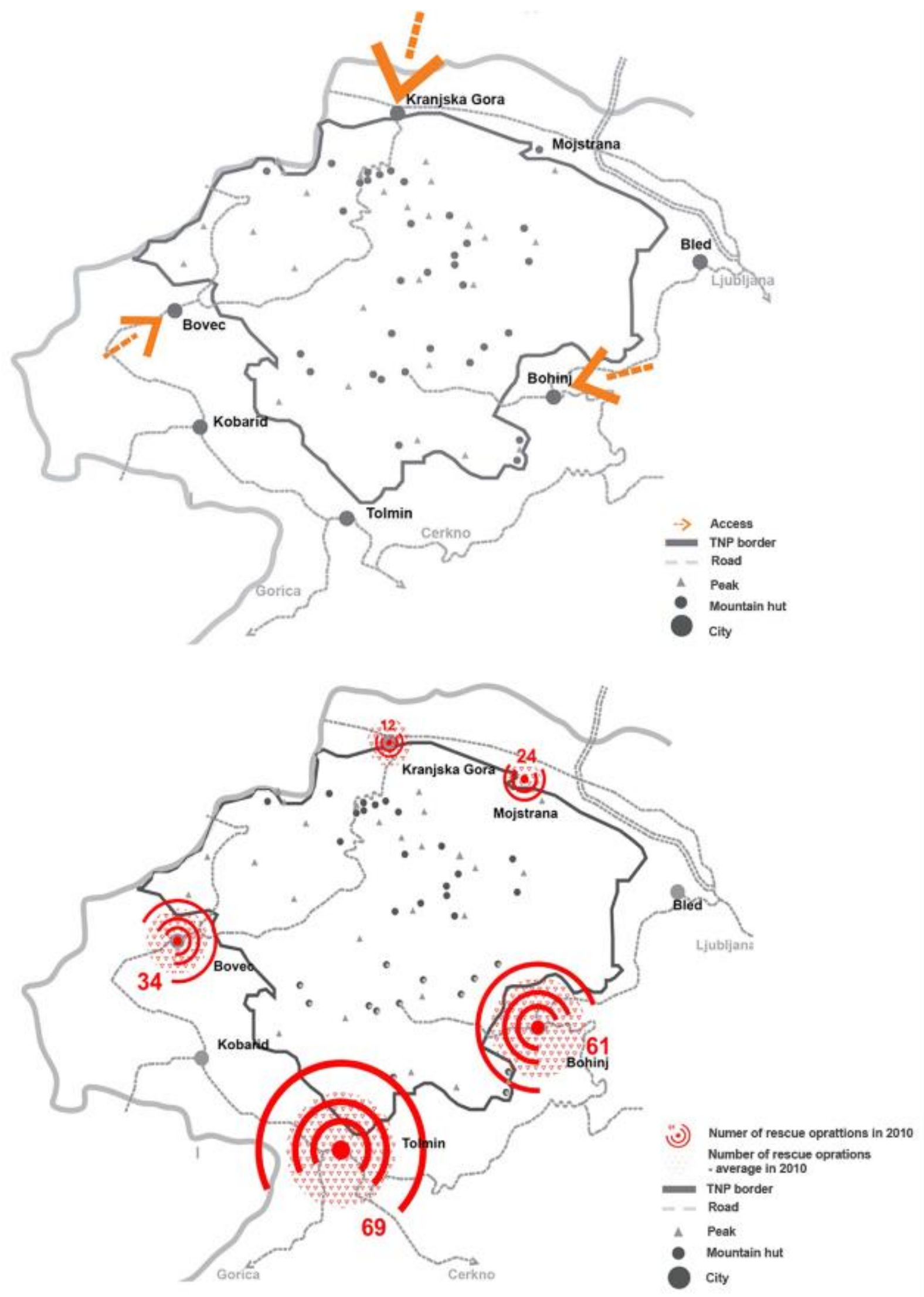

Fig 4. Number of rescue operations in 2010 (data by MRAS, 2011). 


\section{Results and discussion}

By cross-referencing the cartographic materials (maps) produced based on field work and interviews with the inhabitants of TNP, statistical data on the number of inhabitants per settlement unit and the number of accidents in the mountains in individual mountain rescue group districts we found the following:

- The decline in the volume of population is higher and more concentrated on the southern side of TNP (Figure 2),

- In the south slopes of TNP there are many small hamlets, isolated farmsteads and similar smaller settlement patterns, which leads us to the conclusion that the data on the demographic endangerment are related to a wider area, i.e. total area of southern slopes of TNP (Figures 1, 2),

- With regard to unfavourable natural features (landslides, wind conditions, snow cover thickness, extreme temperatures), there are no significant differences between the northern and southern slopes of TNP (Figure 3),

- In 2010, the most mountain accidents happened in the southern slopes of TNP (Figure 4),

- Both negative indicators overlap in the southern slopes of TNP (Figure 5),

- The decline in population in the southern slopes of TNP increases the distance ${ }^{8}$ between the outermost points of settlements and the points of alpine shelters, such as huts and bivouacs, resulting in a higher probability of mountain accidents (Figure 4).

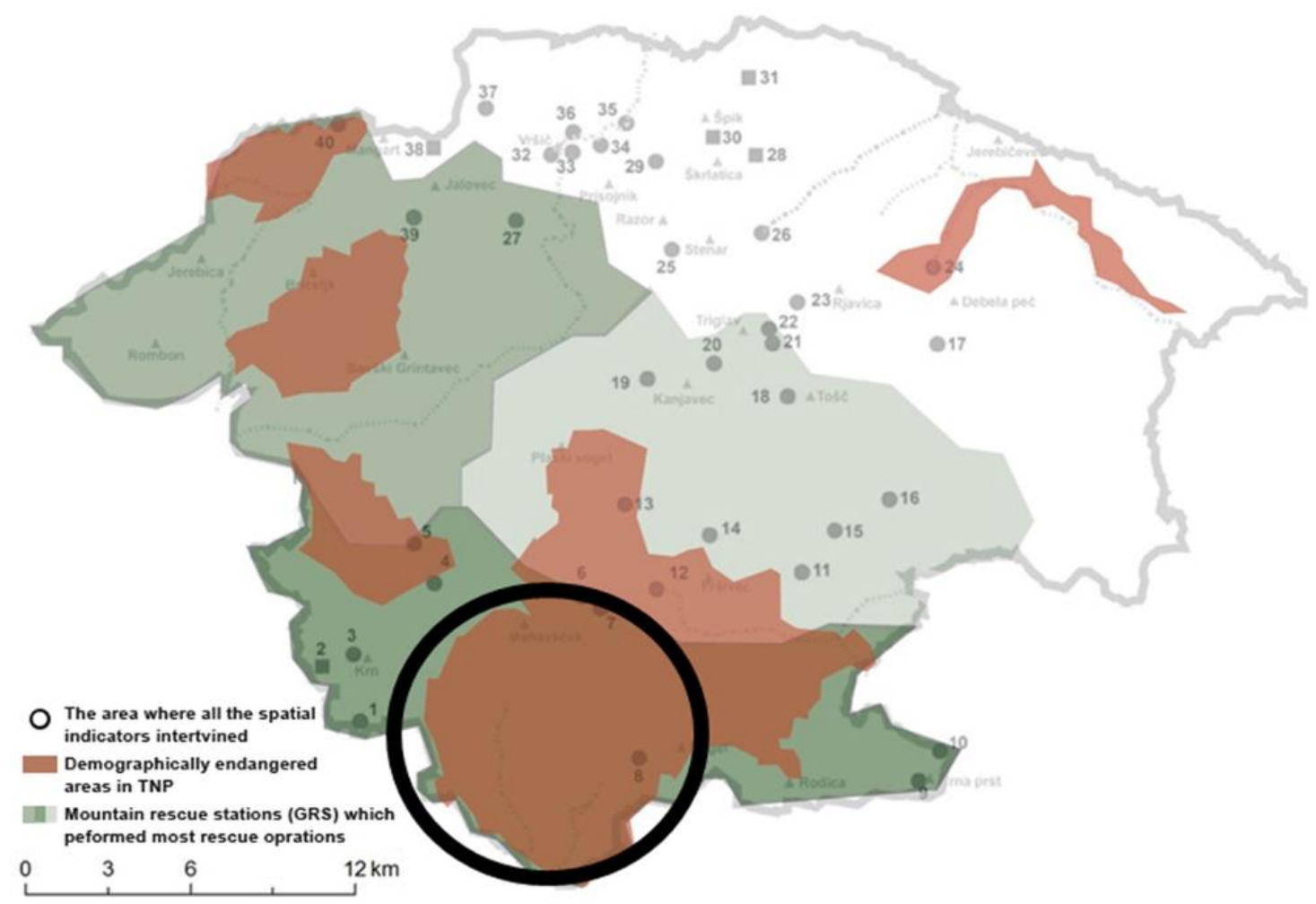

Fig 5. Spatial location of statistical data: analysis of statistical data regarding the number of population and mountain accidents.

\footnotetext{
${ }^{8}$ The estimated distance was defined as a 2-hour walking distance as a function of the target groups: families, recreational athletes, trekkers, active generation, 50+ generation, explorers, i.e. in line with the definitions of the Mountain Paths Act and a survey that was performed as part of the study (distance to an attractive location; Makovec Haložan et al. 2010: 45). A feature of bivouacs is also their location in the natural environment, which is typically remote and not easily accessible (Kajzelj, 1995).
} 
These findings suggest a causal connection between the depopulation of settlements and the increase in the number of mountain accidents in the southern slopes of TNP, as among the investigated natural and man-made features, the demographic gaps are, indeed, the only parameter that significantly differs in the southern slopes of TNP as compared to the northern slopes. As in the introduction, our research question was related to the manifestation of contemporary development concepts of sustainable spatial management, which should in the first place prevent further population decline, we must now, at the end, establish how to connect both negative phenomena (number of mountain accidents and the decline in permanent population) into a development potential.

It is most important to realise that the presence of a hut or a bivouac in the mountains in the range of 1601 - $2000 \mathrm{~m}$ a. s. I. and within a 2-hour walking distance from the first permanently occupied settlement encourages the preservation of alpine settlement structures and offers the opportunity to prevent the accidents which mostly involve the target group defined in footnote 8. In the southern slopes of TNP there is indeed an existing settlement pattern of hamlets, solitary homesteads, dairies and other shelters for livestock and people, fragmented over the entire area, and within the limits of the mentioned parameter; however, in these buildings (and paths) primary agricultural uses have been abandoned and therefore neglected (Figure 6, above). The introduction of new uses, such as accommodation, food, (non)serviced shelters, is a form of tourist development that would help keep alive the abandoned settlement patterns in the high mountain region, while the visitors would be daily provided with care, accommodation, stay, shelter and a safe departure point for climbing the mountains in places which are now frequented but, without serviced shelters, they are difficult of access and dangerous. The validity of the need to improve visitor services in the mountains of TNP is also supported by the note written by Pavel Šegula (1978): »In our regions, mountaineering has become popular as no other sports and recreational activity. In the mountains, you will meet people from every walk of life: easy-going Sunday visitors, occasional tourists, mountain climbers who have been climbing the mountains all their lives, and alpinists."

We may conclude that the introduction of new uses for the needs of alpine tourism into traditionally dispersed settlement in difficult-to-access areas in the southern slopes of TNP improves the safety of visitors and provides a new opportunity for sustainable spatial development, as the revival of the dispersed and versatile settlement pattern enables a quality preservation of natural and built cultural landscape.

Furthermore, we checked the possibility of setting-up the system, i.e. realisation of the idea, of networking of alpine paths between the important points of the settlement pattern by upgrading the existing network and adding new programmatic elements in the form of minor engineering and regulatory interventions. Among the existing mostly overgrown paths, cart tracks and roads, we wanted to select those that best represented the area as a whole and to logically connect them into a functional, user-friendly network (Glavina, 2008: 2). Hence, it made sense to take the existing system of mountain paths, and connect and organise them into a logical whole. This should be based on a maximum 2-hour walking distance between the different types of serviced points, hence allowing for the safety of the user. The network of new paths and the upgrading of the existing ones are designed as tourist infrastructure with a minimum effect on the environment. The design (Figure 6) is based on the selection of suitable roads within the existing network, which is upgraded with new physical connections only where it is absolutely necessary, i.e. to connect the "gaps « and ensure access to service points in a twohour walking radius (see footnote 8 ). The new network of paths is designed as a logically connected set of natural and cultural values upgrading the integration of the individual permanently occupied centres of the settlement pattern of the mountain areas, and temporarily occupied settlements, and huts or bivouacs.

The goal of the organisation of the path network is to find the balance between conservation of the natural environment and human needs - both for the permanent resident and for the ecologically aware tourist - to ensure demographic stability in space.

Space and spatial activities in contemporary mobility represent a new spatial organization (network or networking) which connects the key points in the built and natural structures, while 
through interactions it enhances the value of the area/location. This value is based on the acknowledgment of experiential space, which contains our own experiences and experiences with space: Identity and interactions - the key terms of ecological awareness. In this sense, the networking in space is not limited to the key points, but rather it expands and shrinks in space, bearing in mind the relevant users and their focus. The paths, i.e. spatial networks, are divided based on the subject theme and the manner of use, and they can be combined into several-day round trips. This is left to the ability, demands and imagination of the target group, while the design of the network in space should allow for any number of combinations or scenarios.
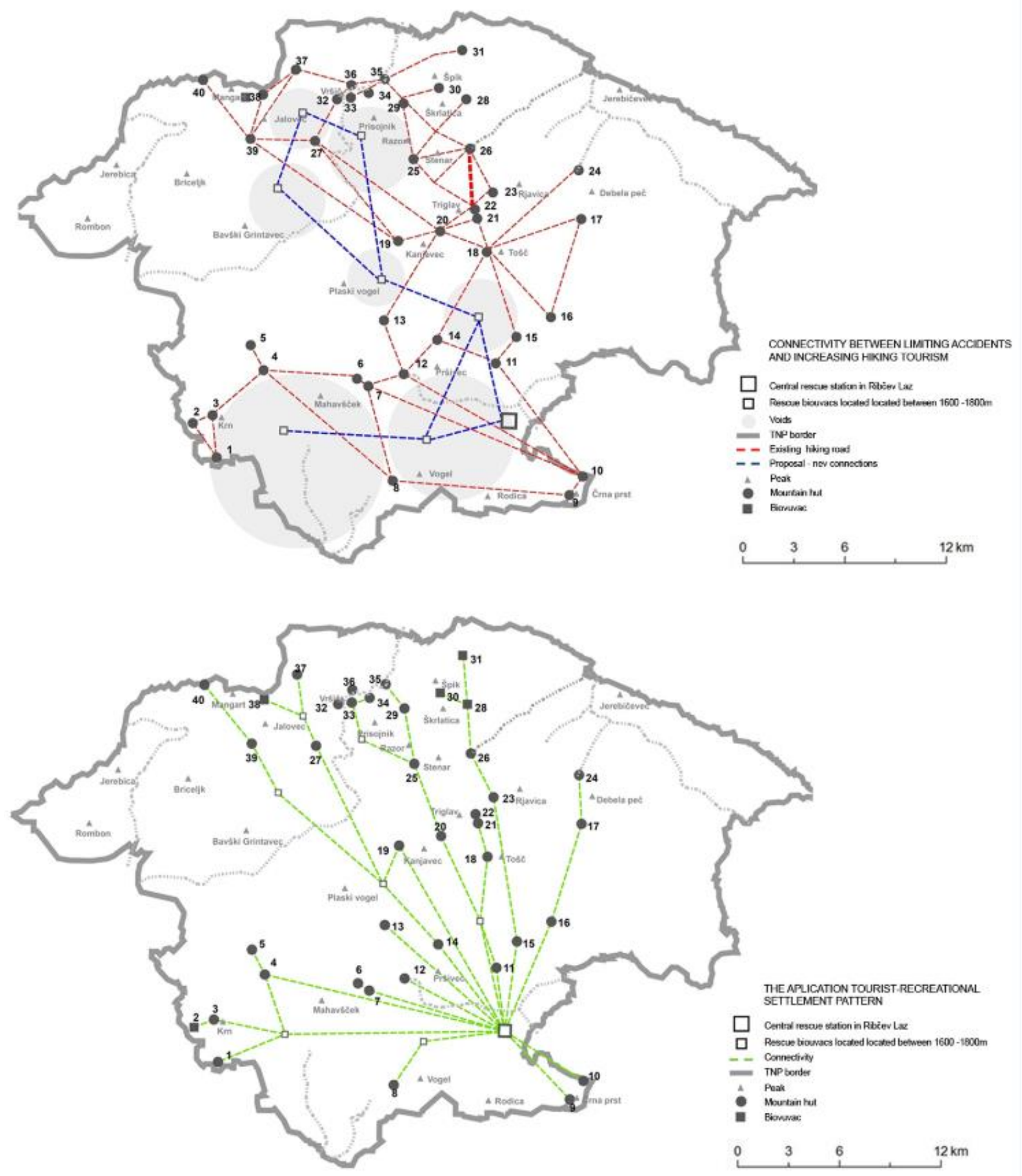

Fig 6. Connectivity between limiting accidents and increasing hiking tourism. 


\section{Conclusions}

The concept of path networking, originating from sustainable principles of spatial management, is based on the upgrading of the system with accommodation capacities. They are designed as refurbished or newly built bivouacs. Density of the bivouac network is measured in term of two hours walking accessibility what ensure more safety environment for hiking tourism. The bivouacs also provide an attractive outdoor installation, which formally complements the existing settlement pattern and architecture expression based on alpine tradition. Networks of paths and network of accommodation capacities in the form of newly or refurbished bivouacs diminish the process of depopulation by new employment possibilities for local population.

Of course, not only tourism development is able to ensure the population stability. As Perlik (2006) states: For regions with attractive landscapes and dynamic local stakeholders in the decisive phases of Alpine tourism, this sector today shapes important local production systems together with agriculture, retailing, construction and crafts. So, the multi-funcional activity is stressed. Further, the population development in European mountain areas is often associated with the amenity migration which is not so much connected with the mountain tourism. Amenity migrants are rather university educated, economically strong and more creative. They prefer natural amenities to cultural ones, their in-migration is not related to tourism and second homes phenomenon. They use current residential potential for permanent living in the amenity-rich places (Bartoš et al.2009).

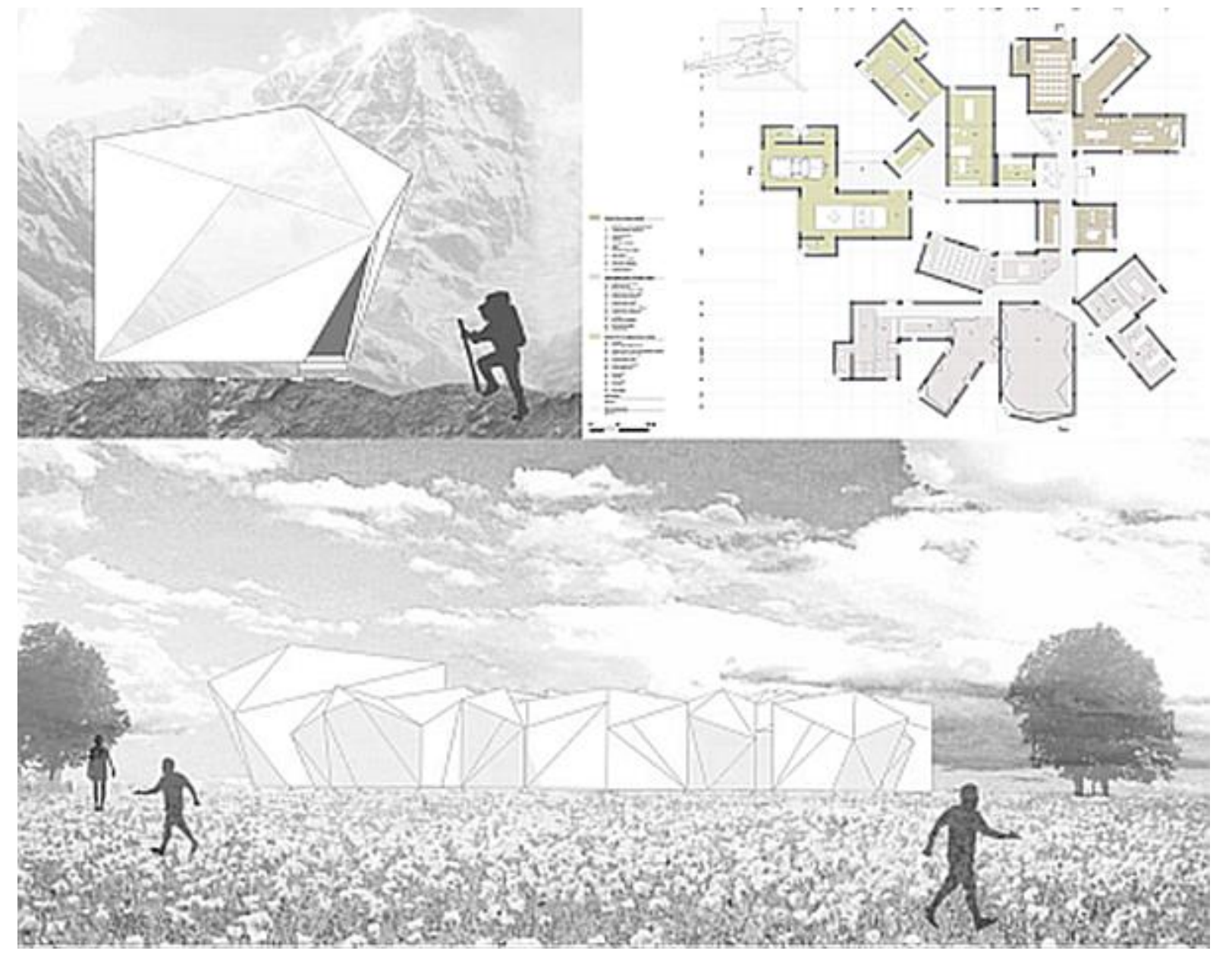

Fig 7. The application of the tourist-recreational settlement pattern (Pandol, 2012).

At the end, we proposed the orientation of further research, which should address complex questions of architectural design of new buildings and other developments in the visually sensitive alpine space, characterised by distinctly recognisable formal identity of the buildings. We presented the application of the architectural model of the tourist and recreation centre Ribčev Laz with rescue bivouacs and a central mountain rescue station. (Figure 7; Pandol, 
2012).The central rescue point is accompanied by a branched-out system of rescue bivouac shelters scattered in the Julian Alps. This will help fill in the voids in dangerous slopes and enable easier access of mountain rescue services to casualties. A new system enabling improved operation of MRAS will be set up. By locating these new mountain shelters we will functionally upgrade and visually unify the existing system of trails and locations of huts/bivouacs. The new units will complement each other visually to offer the user a better spatial orientation on the one hand and on the other to connect the system of trials into a recognizable whole with a very specific design identity on a large scale.

\section{Acknowledgement}

The study represented here is part of the project Competence Centre Sustainable and Innovative Construction (TIGR), as a result of a public tender for the development of competence centres during the period of 2010 - 2013, by the Slovenian Ministry of Higher Education, Science and Technology, where one of the 12 partners was also the Faculty of Architecture of the University of Ljubljana. The amount of co-funding was 6.4 Million EUR. The research presented in this paper was conducted within the mentioned framework.

\section{References}

[1] Ballantyne, R., Packer, J., Hughes, K. (2008). Environmental awareness, interests and motives of botanic gardens visitors: implications for interpretive practice. Tourism management 29(3), 439 - 444. Doi: 10.1016/j.tourman.2007.05.006.

[2] Bartoš, M., Kušová, D., Těšitel, J. (2009). Motivation and life style of the Czech amenity migrants (case study). European Countryside 1(3), 164 - 179. Doi: 10.2478/v10091-0090014-4.

[3] Batzing, W., Perlik, M., Dekleva, M. (1996). Urbanization and Depopulation in the Alps. Mountain Research and Development, 16(4), 335 - 350.

[4] Cigale, D., Lampič, B., Mrak, I. (2010). Turistični obisk in zavarovana območja - primer Triglavskega narodnega parka. Dela, 33, 75 - 96.

[5] Dudley, N., ed. (2008). Guidelines for applying protected area management categories. Gland: IUCN.

[6] Fikfak, A., Rozman, M. (2009). Trajnostni razvoj in ekoturizem: razvoj omrežja turističnih poti. Academica turistica, 2(3/4), 14 - 23.

[7] Garrigós Simón, F. J., Narangajavana, Y., Palacios Marqués, D. (2004). Carrying capacity in the tourism industry: a case study of Hengistbury Head. Tourism management 25(2), 275 - 283. Doi: 10.1016/S0261-5177(03)00089-X.

[8] Glavina, M. (2008). Celovit pristop k zasnovi omrežja pešpoti po Šavrinih [Diploma thesis]. Ljubljana: Univerza v Ljubljani.

[9] Gorska reševalna zveza Slovenije (2011). Analiza nesreč in reševalnega dela v letu 2010. Kranj.

[10] Heggie, T. W., Amundson, M. E. (2009). Dead Men Walking: Search and Rescue in US National Parks. Wilderness and Environmental Medicine, 20(3), 244 - 249. Doi: 10.1580/08-WEME-OR-299R.1.

[11] Holden, A. (2006). Tourism Studies and the Social Sciences. London, New York: Routledge.

[12] Holden, A., Sparrowhawk, J. (2002). Understanding the motivations of ecotourists: the case of trekkers in Annapurna, Nepal. International Journal of Tourism Research 4(6), 435 - 446. Doi: 10.1002/jtr.402. 
[13] Hudman, L. E., Hawkins, D. E. (1989). Tourism in contemporary society. An introductory text. Englewood Cliffs: Prentice Hall.

[14] Jeršič, M. (1999): Slovenske Alpe - kulturna pokrajina - naravni park - športna arena? Dela 13, 47 - 61. Doi: 10.4312/1253.

[15] Jurinčič, I. (2004). Načrtovanje in nadzor turističnega obiska v zavarovanih območjih s pomočjo analize nosilne zmogljivosti. Gosar, A.,ed., Zavarovana območja in njihov pomen za turizem: morska učna pot: Mesečev zaliv in njegovi zakladi. Koper: Univerza za primorskem.

[16] Kajzelj, M. (1995). Alpinska arhitektura [Diplomska naloga]. Ljubljana: Univerza v Ljubljani.

[17] Kajzelj, M. (2011). Bovško: od doline do planine: oris tradicionalnega gospodarjenja. Ljubljana: Debora.

[18] Kirkman, N. F. (1966). Mountain Accidents and Mountain Rescue in Great Britain. British Medical Journal, 1(5480): 162 - 164.

[19] Kladnik, D., Ravbar, M. (2003). Členitev slovenskega podeželja: (prispevek k usmerjanju skladnega regionalnega razvoja). Ljubljana: Založba ZRC SAZU.

[20] Klemenčič, V. (1974). Regionalne razlike in problemi demografske in poselitvene strukture Slovenije. Ljubljana: Demografski institut RCEF.

[21] Lawson, S. R., Manning, R. E., Valliere, W. A., Wang, B. (2003). Proactive monitoring and adaptive management of social carrying capacity in Arches National Park: an application of computer simulation modeling. Journal of Environmental Management 68(3), 305 - 313, Doi: 10.1016/S0301-4797(03)00094-X.

[22] Lemon, R., Percy, S., Wright, P. et. al. (2004). Education for sustainable development. A manual for Schools. Birmingham City Council, The Royal Town Planning institute, University of West England.

[23] Lovén, L. (2000). Koli National Park - site of solitude and heritage. In: Lovén L., ed., Responsible nature tourism. Proceedings of the conference at Koli National Park, Joensuu: Finnish Forest Research Institute.

[24] Makovec Haložan, M., Bedrač, R., Čeh, D., Sekirnik, J., Lenarčič, M., Prah, J., Tomše, T., Vidovič, U., Puklavec, M., Pak, M. (2010). Študija o označevanju in vzdrževanju tematskih pohodnih poti. Center za zdravje in razvoj Murska Sobota, Znanstveno-raziskovalno središče Bistra Ptuj, Pohodništvo in kolesarjenje GIZ, Zavod za gozdove Slovenije in Turistična zveza Slovenije, Planinska zveza Slovenije, RISO ZAVOD, Slovenska turistična organizacija.

[25] Marolt, M., Smukavec, U., Zupan, S., Mlekuž, Ž. (2012). Socio-ekonomska analiza Triglavskega narodnega parka. In: Kus Veenvliet J.(ed..), Izhodišča za Načrt upravljanja Triglavskega narodnega parka 2012 - 2022. Bled: Javni zavod Triglavski narodni park.

[26] Nared, J. (2004). Prostorski učinki zakona o spodbujanju razvoja demografsko ogroženih območij $v$ republiki Sloveniji. IB revija: za strokovna in metodološka vprašanja gospodarskega, prostorskega in socialnega razvoja Slovenije, 38(1/2), 4 - 16.

[27] Ogrin, M., Kebe, L., Šegina, A., Žnidarčič, T. (2011). Alpska konvencija v Sloveniji in njeno izvajanje na lokalni ravni: usmeritve za občine s primeri dobre prakse. Innsbruck: Stalni sekretariat Alpske konvencije.

http://www.alpconv.org/documents/Permanent_Secretariat/web/library/Comuni\%202010_S L.pdf (accessed February 10, 2012)

[28] Pallarés-Blanch, M., Prados, M.-J., Tulla, A. (2014): Naturbanization in Spain: Case study of new rural landscapes in Andalusia and Catalonia. European Countryside 6(2), 118 - 160. Doi: 10.2478/euco-2014-0008.

[29] Pandol, N. (2012). Idejna zasnova gorske reševalne postaje znotraj TNP [Diplomsko delo]. Ljubljana: Univerza v Ljubljani. 
[30] Perlik, M. (2006): The specifics of amenity migration in the European Alps (pp. 215 - 231). In Moss, L.A.G., ed., The amenity migrants. Wallingford: CABI.

[31] Plut, D. (1999). Pokrajinski vidiki sonaravnega razvoja zavarovanih območij slovenskih Alp. Dela, 13, 103 - 113.

[32] Prato, T. (2001). Modeling carrying capacity for national parks. Ecological economics 39(3), 321 - 331. Doi: 10.1016/S0921-8009(01)00248-8.

[33] Prebilič, V., Svete, U. (2006). Organizing system of protection and rescue in snow avalanches - new challenges for Alpine rescue service in Slovenia. $5^{\text {th }}$ ICA Mountain Cartography Workshop Bohinj http://www.geod-is.si/mcws06/1_3.pdf_(accessed June 20, 2012).

[34] Reinius, S. W., Fredman, P. (2007). Protected areas as attractions. Annals of Tourism Research 34(4), 839 - 854. Doi: 10.1016/j.annals.2007.03.011.

[35] Šegula, P. (1978). Nevarnosti v gorah. Ljubljana: Planinska zveza Slovenije.

[36] Shimanski, C. (2008). Accidents in mountain rescue operations. Evergreen (CO): Mountain Rescue Association.

[37] SI-STAT data portal. http://pxweb.stat.si/pxweb/dialog/statfile2.asp (accessed January 10, 2012).

[38] TIES (The International Ecotourism Society) (1990). Ecotourism Statistical Fact Sheet. http://www.ecotourism.org (accessed January 16, 2012).

[39] Uredba o območjih, ki se štejejo za demografsko ogrožena območja v Republiki Sloveniji. Uradni list RS, No. 19/1999, 26. 3. 1999.

[40] Van der Merwe, P., Saayman, M. (2008). Travel motivations of tourists visiting Kruger National Park. Koedoe 50(1), 154,- 159.

[41] Zakon o spodbujanju skladnega regionalnega razvoja (ZSRR) (Act for Promotion of Balanced Regional Development Act). Uradni list RS, No. 60/1999, 29. 7. 1999 (56/2003, 83/2003-UPB1, 93/2005). 